\title{
THE MODE OF DEVELOPMENT OF URINARY INFECTION IN INTERMITTENTLY CATHETERISED MALE PARAPLEGICS
}

\author{
By D. J. Stickler, B.Sc., D.Phil., C. B. Wilmot, M.B., B.CH., and \\ J. D. O'FLYNN, M.CH., F.R.C.S.(Ed.), F.R.C.S.I. \\ National Medical Rehabilitation Centre of Ireland, Our Lady of Lourdes Hospital, Dublin. \\ Departments of Bacteriology and Surgery, Trinity College, Dublin
}

IN the Republic of Ireland patients with spinal injuries are flown by a helicopter service to the National Medical Rehabilitation Centre as soon as possible after injury so the Centre is responsible for the management of the patient's bladder from the very early stages of spinal shock. For many of the cases, intermittent catheterisation is used for the early treatment of retention associated with the paraplegia, (Guttmann \& Frankel, I966), and while with the use of this technique a sterile urine can be maintained for a long period of time, urinary infections do still occur (Wilmot \& O'Flynn, I967).

The possible modes by which bacteria gain access to the bladder during catheterisation have been the subject of much discussion (Guze \& Beeson, I956; Miller, I965; Roberts, Linton, Pollard, Mitchell \& Gillespie, I965; Desautels, I969).

There seems to be general agreement that given proper sterilisation of the catheter, good aseptic technique by the operator, and adequate disinfection of the external genitalia infection might still be introduced into the bladder from the urethra. The present study was undertaken to determine $(a)$ whether in the case of paraplegics undergoing intermittent catheterisation, the organisms eventually responsible for the infection do in fact become part of the flora of the urethra and its external meatus prior to their invasion of the bladder and $(b)$ whether the regular bacteriological examination of the urine and the urethra of such patients would give early warning of an impending urinary infection.

\section{METHODS}

Catheterisation. Intermittent catheterisation was carried out with a size I4 or I6 plastic catheter on an eight hourly basis. Occasionally, if the patient was producing large quantities of urine, then the catheterisation was more frequent. The catheter was passed with the usual aseptic precautions (Guttmann \& Frankel, I966), the glans being cleansed with an aqueous solution of hibitane (0.06 per cent.).

Collection of Samples. As far as possible the following samples were taken daily up to the time of development of a urinary infection. During the first catheterisation of the day swabs were taken from the urethral meatus before and after the penile cleansing. The urethra was then irrigated with sterile saline (Io ml.) using a sterile glass syringe and the washout collected into a sterile container. It was considered that these washout samples registered not only the urethral flora but also organisms from the area around the external meatus. This was not entirely satisfactory, but the other methods that have been devised for 
examining the urethral flora, e.g. using the first 5 to $\mathrm{Io} \mathrm{ml}$. of the voided urine (Stamey, Govan \& Palmer, 1965), or the use of a special rubber cot which can exfoliate into the urethra (Cox, Lacy \& Hinman, I968), could not be applied to the patients in the present study.

Bacteriological Procedures. The samples were stored at $4^{\circ}$ immediately after collection and were cultured aerobically at $37^{\circ}$ on blood and MacConkey agars. Viable counts of bacteria were made on the urines and urethral washouts and the various organisms isolated were identified using the methods of Cowan and Steel (1965). Strains of Pseudomonas aeruginosa were typed by the pyocine method of Govan and Gillies (I969).

Criteria of Infection. A level of $100,000 \mathrm{bacteria} / \mathrm{ml}$. of urine recorded on two or more consecutive samplings is considered as an established urine infection, bacterial growth having occurred in the stagnant bladder urine. In the neurogenic bladder this is dangerous and likely to lead to a genuine urinary tract infection, which is detected as 100,000 bacteria $/ \mathrm{ml}$. of urine plus pyuria.

\section{RESULTS}

A total of nine patients were examined and the data accumulated are presented here as a series of case reports (figs. I-9). The following abbreviations have been used in tabulating the results: $-\mathrm{S}=$ Staphylococcus, Ps = Pseudomonas, $\mathrm{P}=$ Proteus, $\mathrm{B}=$ Bacterium, $\mathrm{K}=\mathrm{Klebsiella}$. The nomenclature used is that recommended by Cowan and Steel (1965). S. epidermidis was formally referred to as S. albus and Ps. aeruginosa as Ps. pyocyanea. Of the patients in this study only one (Patient N. 8) had been circumcised prior to catheterisation.

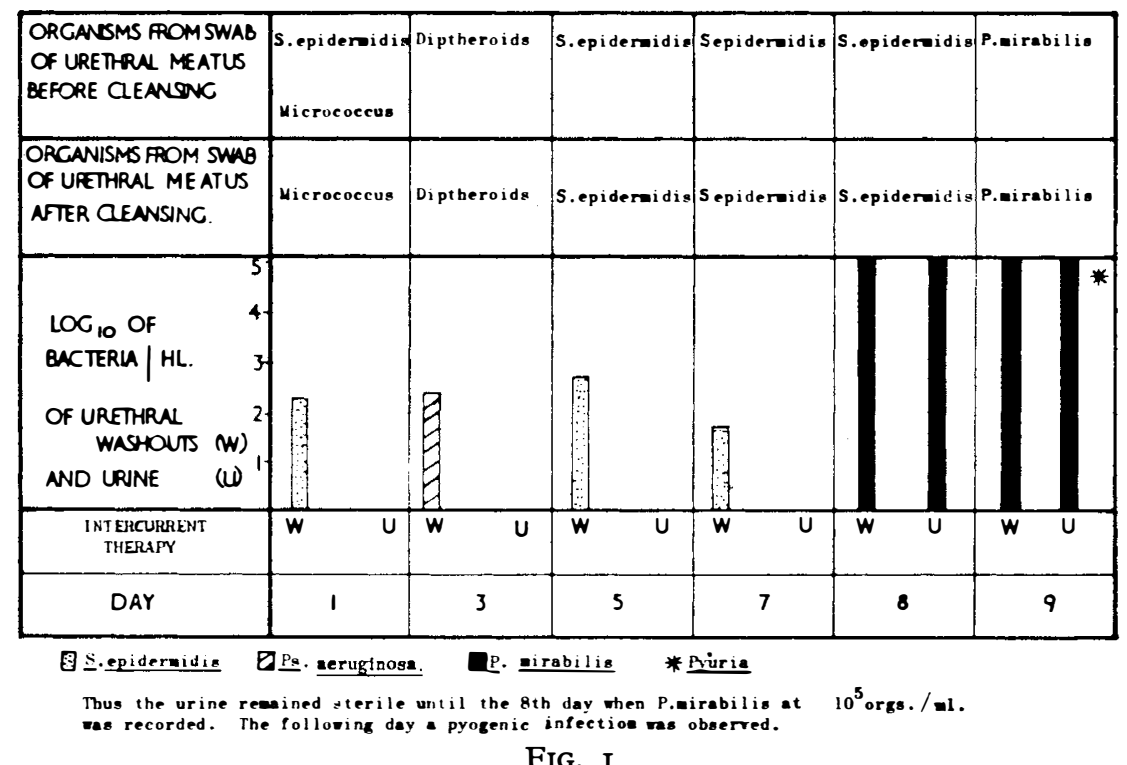

Results from patient I, J. W., I9 years of age, with an incomplete lesion at TI2. The accident-admission interval was 7 hours and the patient started to micturate on day 8. 


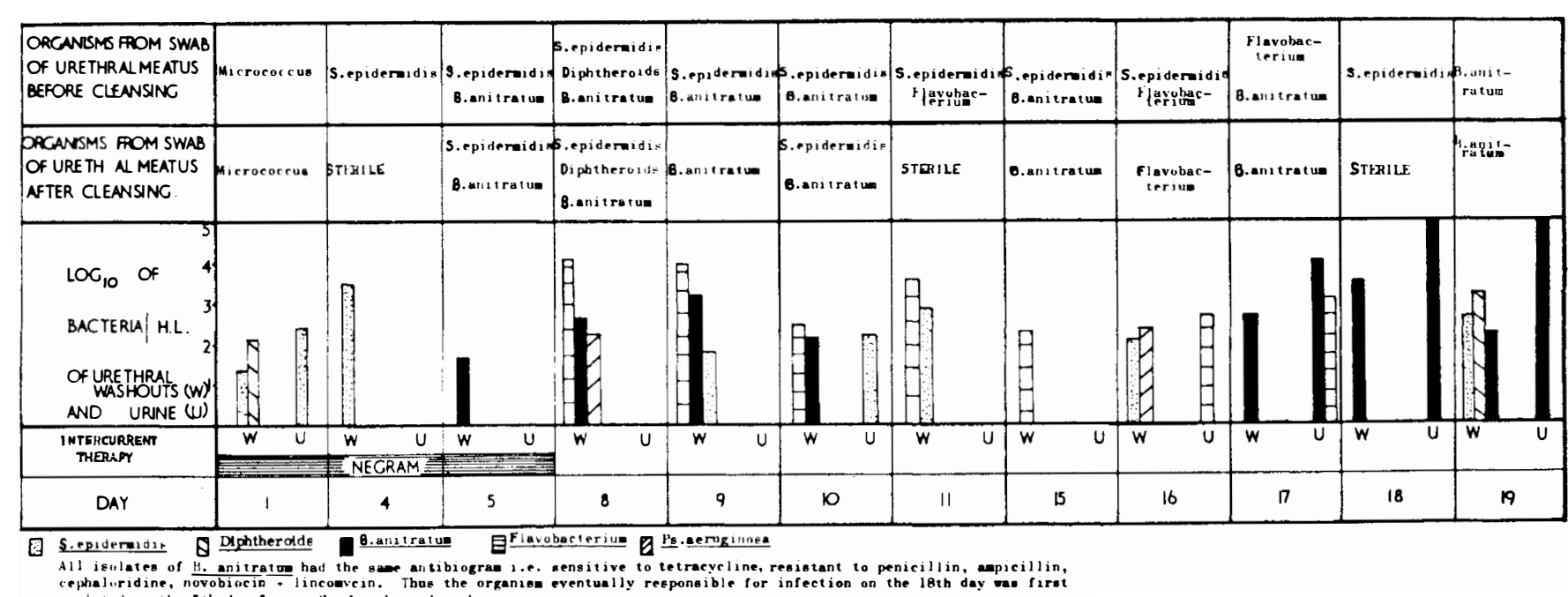

FIG. 2

Results from patient 2, M. M., 52 years of age, with a complete lesion at T3. The accident-admission interval was 16 hours. 


\begin{tabular}{|c|c|c|c|c|c|c|c|c|c|c|c|}
\hline 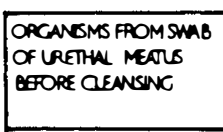 & pideraidi & $\mid \begin{array}{l}\text { ids.epidersidis } \\
\text { Dipht ther i ids }\end{array}$ & S.epideraid & $\begin{array}{l}\text { S.epidersodis } \\
\text { Oiphtherouts }\end{array}$ & $\begin{array}{l}\text { S.epideraidid } \\
\text { Di pht heroide }\end{array}$ & 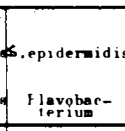 & 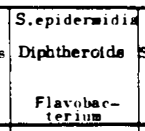 & 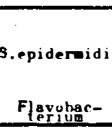 & erraid th & Fiavobace & 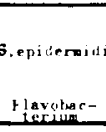 \\
\hline $\begin{array}{l}\text { ORCANSMS FOMM SWAB } \\
\text { OF LRETHRA MEATUS } \\
\text { NTER CLENSENC }\end{array}$ & STERILt. & $\begin{array}{l}\text { S.epidersidis } \\
\text { Diphtheroide }\end{array}$ & Diphtheroid & $\begin{array}{l}\text { S.epideraidas } \\
\text { Dipht theroids }\end{array}$ & STERILE & B.epidersidi & $\begin{array}{c}\text { S.epidersidis } \\
\text { Dhphtherolda } \\
\text { Flavobac- } \\
\text { terius }\end{array}$ & $\begin{array}{c}\text { Flavobac- } \\
\text { teritue }\end{array}$ & STRRLLE & S.epideraidis & STERILE \\
\hline 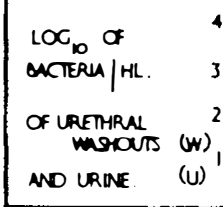 & . & 易 & 至 & H & B & 是 & 思 & $\begin{array}{l}B \\
\theta\end{array}$ & & $\begin{array}{l}0 \\
\theta\end{array}$ & 晶 \\
\hline $\begin{array}{l}\text { Inter Curront } \\
\text { merepy }\end{array}$ & $w$ & & & & $u$ & & w & $w$ & $w$ & w & $w$ \\
\hline DAY & 1 & 4 & 16 & 17 & 18 & 19 & 22 & 23 & 24 & 25 & 26 \\
\hline
\end{tabular}

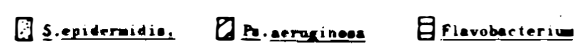

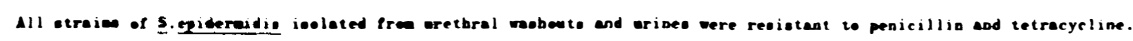

FIG. 3

Results from patient 3, E. F., I8 years of age, with an incomplete lesion at $\mathrm{C}_{4}$. Accident-admission interval was 12 hours. 


\begin{tabular}{|c|c|c|c|c|c|c|c|c|c|c|}
\hline $\begin{array}{l}\text { ORCANSMS FOM SWMB } \\
\text { OF URETHRAL MEATUS } \\
\text { BEFORE Q EANSINC }\end{array}$ & Sepidermidie & S.epidernidig & $\begin{array}{l}\text { S.epidereidis } \\
\text { Alcaligentes }\end{array}$ & $\mid \begin{array}{l}\text { S.epidereadis } \\
\text { Alicaligenes }\end{array}$ & Sepideraidis & S.epideraidia & Sepiderenidie & $\begin{array}{l}\text { Alcaicelle: } \\
\text { Ps.aeruginase }\end{array}$ & $\begin{array}{l}\text { S.epideraidin } \\
\text { Alcaligene } \\
\text { Ps.aerugunosa }\end{array}$ & N.T. \\
\hline $\begin{array}{l}\text { LOC OF } \\
\text { BACTERIA } / \mathrm{HL} \\
\text { OF URFTHRAL } \\
\text { WASHOUTS (W) } \\
\text { AND URINE }\end{array}$ & 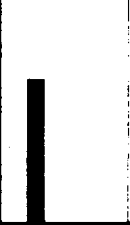 & 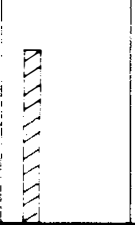 & $\begin{array}{l}2 \\
2 \\
2 \\
2 \\
3 \\
3 \\
3\end{array}$ & 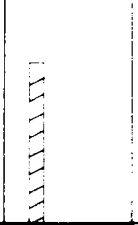 & & $y$ & 8 & 5 & $E$ & N.T \\
\hline $\begin{array}{l}\text { INTERCUIUIGKT } \\
\text { THER:YY }\end{array}$ & $\begin{array}{ll}W \quad U \\
\end{array}$ & $\begin{array}{cc}W & U \\
\text { AMPLOLIN }\end{array}$ & $\begin{array}{ll}W & U \\
& \end{array}$ & $W \quad U$ & $w$ & $w$ & $w$ & $U$ & $U$ & $w$ \\
\hline DAY & 1 & 2 & 4 & 5 & 8 & 9 & 10 & II & 12 & 16 \\
\hline
\end{tabular}

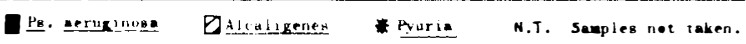

Ail inolates of pe.eeruglinose rere pyocine type 3 .

P's. arruginisu thus reached infection level in the urine on the 12 th day. The saes strain had bowever, been

ianlated on the three previous tays froe the urethral mahout and there as alow build up in the urinary

concentration of this organian froe the loth day. A pyogenic infection eventally developed.

FIG. 4

Results from patient 4, R. W., 2 I years of age, with an incomplete lesion at T8. The accident-admission interval was 16 hours.

FIG. 5

Results from patients 5, G. N., 44 years of age, with an incomplete lesion at C6. Retention that had followed cervical laminectomy had been relieved by an indwelling catheter for 7 days prior to admission. This catheter was removed and intermittent catheterisation was carried out.

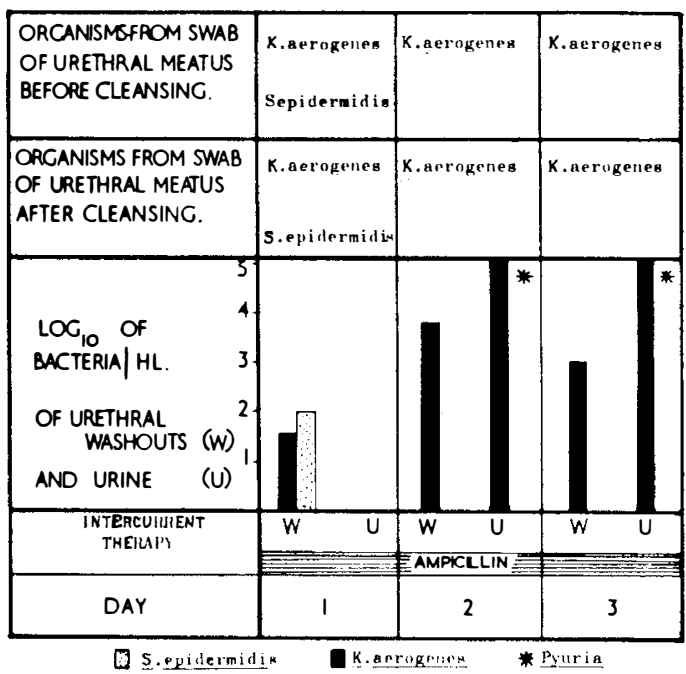

All the isolates of Kafrugenes had the same antibingram heing reaistant 0 ampicillin, tetrcycline, kanamycin, and cephaloridine, gensitive to colistin, nitrofurantoin and nalidixic acid. 


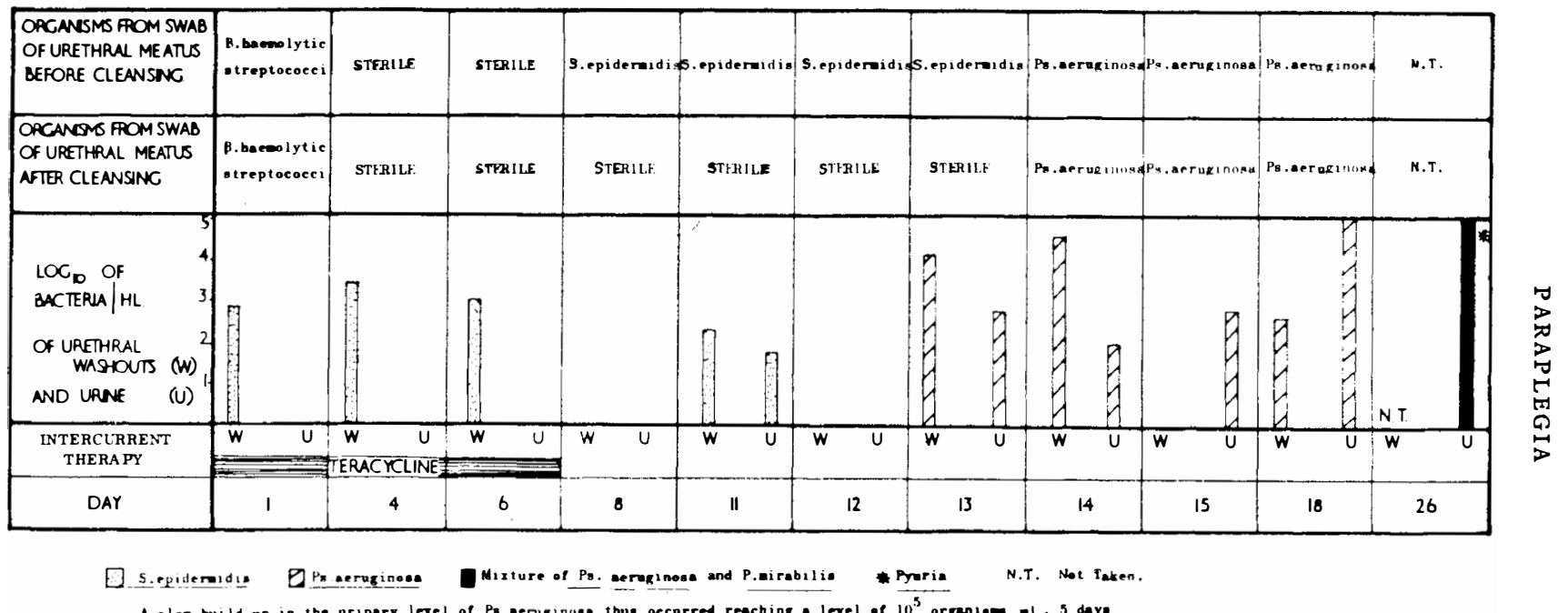

FIG. 6

Results from patient 6, P. M., I5 years of age, with an incomplete lesion at $\mathrm{C}_{4}$. The accident-admission interval was 4 hours and the patient started to pass urine on the 17 th day. 


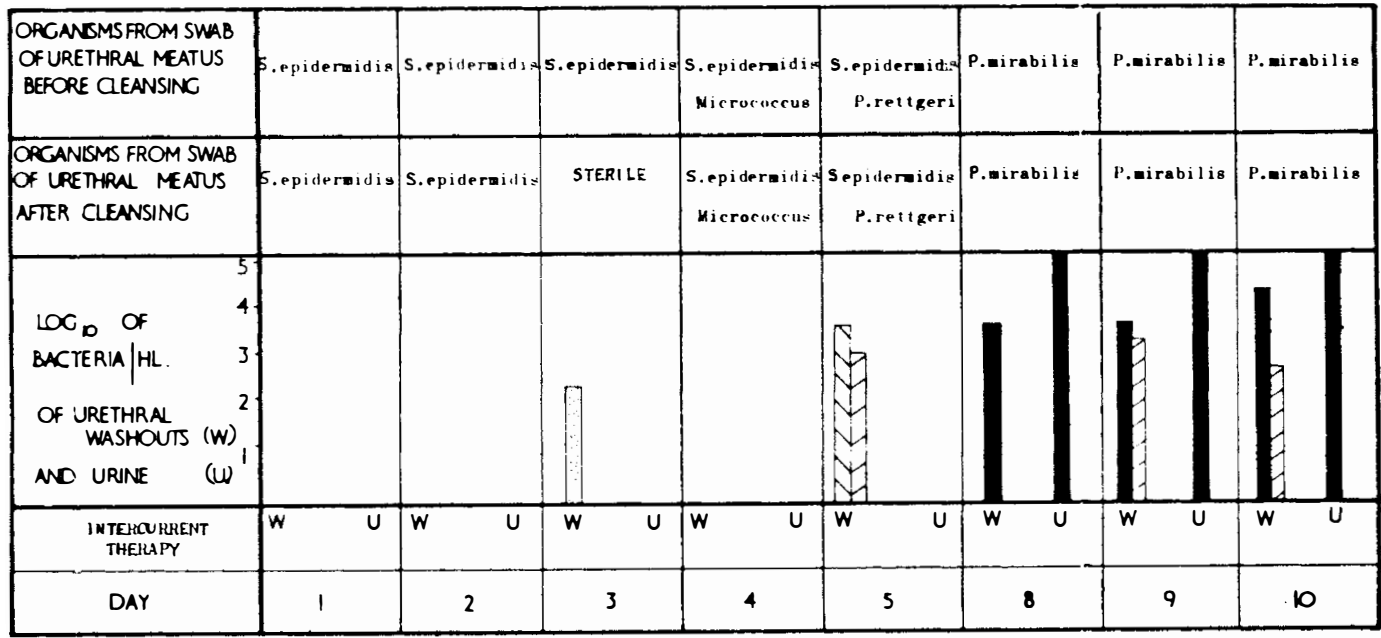

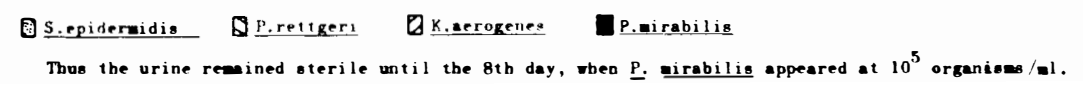

FIG. 7

Results from patient 7, P. W., 47 years of age, with an incomplete lesion at $\mathrm{C}_{3}$. The accident-admission interval was 8 hours. The patient started to pass urine on the 6th day.

\begin{tabular}{|c|c|c|c|c|c|c|c|c|c|}
\hline $\begin{array}{l}\text { ORGANISMS FROMSWAB } \\
\text { OF URETHRAL MEATUS } \\
\text { BEFORE CLEANSINC }\end{array}$ & S.epidermidis & S.epidermidis & S.epideraidia & N.T & $\begin{array}{r}\text { S.epideraidid } \\
\text { Micrococcus }\end{array}$ & $\begin{array}{l}\text { P.mirabilis } \\
\text { P.morgonii }\end{array}$ & $\begin{array}{l}\text { P.mirabilig } \\
\text { P.morganii }\end{array}$ & N.T. & \\
\hline $\begin{array}{l}\text { ORGANISMS FROM SWAB } \\
\text { OF URETHRAL MEATUS } \\
\text { AFTER CLEANSINC }\end{array}$ & S.epidernidis & S.epideraidif & S.epidernidia & N.T & S.epideraidin & $\begin{array}{l}\text { P.mirabilis } \\
\text { P.morganii }\end{array}$ & $\begin{array}{l}\text { P.mirabilis } \\
\text { P.morganii }\end{array}$ & N.T & \\
\hline $\begin{array}{l}\text { LOC } 10 \text { OF } \\
\text { BACTERIA } \mid \mathrm{HL} . \\
\text { OF URETHRA } \\
\text { WASHOUTS (W) } \\
\text { AND URINE } \\
\text { (U) }\end{array}$ & & & & & & $B$ & & & * \\
\hline $\begin{array}{l}\text { INTERCURHENT } \\
\text { THERA IY }\end{array}$ & U & $\frac{U}{G E N T A C I N=}$ & U & $\begin{array}{r}U \\
\square\end{array}$ & $U$ & U & $U$ & $U$ & \\
\hline DAY & 1 & 4 & 6 & 7 & 6 & II & R & $B$ & \\
\hline
\end{tabular}

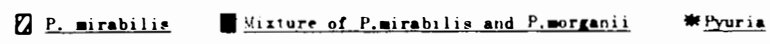

Thus the urine reasined sterile until the 11 th day wen p.eirabilis was present at 25,400 organisa / $61 .$. The following day $10^{5}$ organisas a was reached in the urine by aized cultore of p.urabilis and p.morkanii and on day 13 a pyogenic infection was present.

FIG. 8

Results from patient 8, M. McG., 25 years of age, with a complete lesion at $T_{3}$. The accident-admission interval was 5 hours. Urethral washouts were not taken from this patient. 


\begin{tabular}{|c|c|c|c|c|c|c|c|c|}
\hline $\begin{array}{l}\text { ORGANUSMSFROM SWAB } \\
\text { OF URETHRAL MEATUS } \\
\text { BEFORE CLEANSNC }\end{array}$ & Sepideraidis & $\left\{\begin{array}{l}\text { S.epidernidis } \\
\text { Micrococcus }\end{array}\right.$ & $\begin{array}{l}\text { S.epidereidis } \\
\text { Micrococrus }\end{array}$ & $\begin{array}{r}\text { S.epidernidin } \\
\text { Micrococcus }\end{array}$ & $\begin{array}{c}\text { S.epidersids } \\
\text { Micrococrus }\end{array}$ & K.aerogenes & K.aerogenes & K.aerogenes \\
\hline $\begin{array}{l}\text { ORGANISMS FROM SWAB } \\
\text { OF URE THRAL MEAUUS } \\
\text { AFTER CEEANSINC }\end{array}$ & STERILE & STERILE & STERILE & $\left|\begin{array}{l}\text { S.epidereidin } \\
\text { Micrococecus }\end{array}\right|$ & S.epidermida & X.aerogenes & STERILE & X.aerogenes \\
\hline $\begin{array}{l}\text { LOC D OF } \\
\text { BACTERIA } \mid \mathrm{HL} . \\
\text { OF URETHEAL } \\
\text { WASHOUTS } \\
\text { AND URINE }\end{array}$ & & & & & & 8 & 8 & 是 \\
\hline $\begin{array}{c}\text { INTERCURHENT } \\
\text { THERAYY }\end{array}$ & \begin{tabular}{|c|}
$U$ \\
ORBENNIN+ \\
\end{tabular} & $\frac{U}{1 \text { STREPTOMYCIN }}$ & $U$ & $u$ & $u$ & U & $u$ & $u$ \\
\hline DAY. & 1 & 2 & 6 & 9 & 10 & 11 & 12 & 13 \\
\hline
\end{tabular}

FIG. 9.

Results from patient 9, P. W., 26 years of age, with an incomplete lesion at C6. The accident-admission interval was 12 hours. Urethral washouts were not taken from this patient.

\section{DISCUSSION}

Govan, Butler and Engelsjerd (I968), observed the pathogenesis of urinary tract infections associated with neurogenic bladder dysfunction in patients that had recovered from spinal shock and were fitted with a condom drainage apparatus for the transfer of the voided urine from the urethra to a container. In four patients they found that bladder infection developed with the same species of bacteria that had previously been documented in urethral cultures. The results of the present investigation indicate that a similar situation can be observed in patients undergoing intermittent catheterisation. Thus with patients $2,3,4$ and 5 the organisms eventually responsible for the infection were isolated from the urethral washouts or swabs prior to their appearance in the urines. In the cases of patients 6 and 8 the infecting organisms were isolated from the swabs or washouts when the number of organisms in the urine was below $10^{5} / \mathrm{ml}$.

It is perhaps surprising that Escherichia coli was not isolated from any of these patients, however, the spectrum of organisms responsible for urinary tract infections in paraplegics tends to be different from that in non-paraplegic cases (Milner, 1963). The organisms isolated during the present study are similar to those considered by Gould (I968) to reflect contamination of the urinary tract to some external source in the hospital environment rather than self-contamination from the intestinal tract of the patient. An interesting feature of these results is that they seem to suggest that the various organisms introduced into the urinary tract proliferate at different rates. Proteus mirabilis (patients I, 7 and 8) and Klebsiella aerogenes (patients 5 and 9) multiply rapidly and quickly reach a level of more 
than 100,000 organisms/ml. of urine. Other organisms, for example Pseudomonas aeruginosa on introduction into the tract do not always establish themselves in the urine and if they do, then they take time to reach a urinary level of $10^{5}$ organisms $/ \mathrm{ml}$. ( 3 and 5 days in patients 4 and 6 respectively) Bacterium antitratum has been reported as a urinary pathogen for paraplegics (Milner, 1963), but it too appears to take considerable time to build up to an established urine infection (patient 2). Staphylococcus epidermidis is generally considered as a skin commensal that can only occasionally act as a low-grade pathogen in the urinary tract (Cowan \& Steel, 1965). In the case of patient 3 , it was isolated from the urine on five consecutive occasions and for the last three days at greater than $10^{5}$ organisms $/ \mathrm{ml}$. However, it took 24 days from the time of the introduction of this organism into the urinary tract to reach infection levels in the urine. Further, although this species was isolated from all the other patients in the study only in the one case did it establish an infection. This reinforces the view that $S$. epidermidis has only a low level of virulence for the urinary tract. A number of organisms were isolated during the course of this study, e.g. Alcaligenes, Flavobacterium, Micrococcus and diphtheroids, which apparently have no ability to cause infection.

The slow development of some organisms in the bladder urine and the fact that in patients $I, 4,6,8$ and 9 the invading bacteria were present in the urine at $10^{5}$ organisms $/ \mathrm{ml}$. prior to their producing a pyogenic infection suggests that with the regular examination of urines and the close co-operation between bacteriologists and clinicians, as advocated by Tribe and Silver (1969), many of the bacterial invasions of the urine might be detected and treated before they have infected the tissue of the urinary tract.

An observation of practical importance is that the penile cleansing with hibitane was seldom sufficient to sterilize the external meatus of the urethra prior to the introduction of the catheter. Attempts are now being made to improve these disinfection procedures.

\section{SUMMARY}

Observations have been made on the development of urinary infections in nine patients being intermittently catheterized during the early stages of paraplegia. The results indicate:

I. In four of the nine cases the organisms eventually responsible for the infection could be isolated from the urethra or its external meatus before they invaded the urine.

2. There is variation in the rate at which different organisms establish themselves in the urinary tract and reach a level of $10^{5}$ organisms $/ \mathrm{ml}$. in the urine.

3. In five of the nine cases studied the invading bacteria were present at $10^{5}$ organisms $/ \mathrm{ml}$. of urine prior to the production of a pyogenic infection.

4. The penile cleansing performed before the insertion of the catheter rarely sterilised the external meatus of the urethra.

\section{RÉSUMÉ}

Des observations ont été effectuées en ce qui concerne des infections urinaires chez 9 malades traités par sondages intermittents pendant la phase du début de la paraplégie. Les résultats indiquent que: 
I. Chez 4 des 9 cas, les organismes responsables de l'infection ont pu être isolés de l'urètre ou au niveau du méat avant l'infection urinaire proprement dite.

2. Il y a une variation de croissance des différents organismes jusqu'à ce qu'ils atteinnent un chiffre de $10^{5}$ organismes par ml d'urine.

3. Chez 5 des 9 cas étudiés, les bactéries responsables étaient présentes à un chiffre de $10^{5}$ par $\mathrm{ml}$ avant l'apparition d'une pyurie.

4. Le méat est rarement désinfecté par le nettoyage avant l'insertion de lasonde.

\section{ZUSAMMENFASSUNG}

In 9 Patienten, die während des Frühstadium der Paraplegie mit intermittierender Katheterisierung behandelt waren, wurden Beobachtungen über die Entwicklung von Urininfektionen gemacht. Die Resultate ergaben:

I. In 4 von 9 Fällen konnten für die entgültige Infektion verantwortlichen Organismen von der Urethra oder dem äusseren Meatus isoliert werden, bevor sie in den Urin eindrangen.

2. Die Geschwindigkeit mit der sich die verschiedenen Organismen im Urine etablieren und einem $\mathrm{Grad}$ von $10^{5}$ Organismen $/ \mathrm{ml}$ im Urine erreichen, variiert.

3. In 5 von 9 untersuchten Fällen waren die eindringenden Bakterien bei $10^{5}$ Organis$\mathrm{men} / \mathrm{ml}$ in Urin vor der Produktion einer pyogenen Infektion vorhanden.

4. Die Reinigung des Penis bevor Insertion des Katheters sterilisiert den Meatus externus der Urethra nur selten.

Acknowledgments. We are grateful to Dr. R. R. Gillies and Professor E. Moorhouse for the pyocine typing of Ps. aeruginosa and to the Biomedical Research Trust for a grant.

\section{REFERENCES}

Cowan, S. T. \& SteEL, K. J. (1965). Manual for the Identification of Medical Bacteria. Cambridge University Press.

Cox, C. E., LACY, S. S. \& HinMan, F. (1968). F. Urol. 99, 632.

DESAUTELS, R. E. (1969). F. Urol. 101, 757.

Gould, J. C. (I968). In Urinary Tract Infection. Eidted by F. O'Grady and W. Brumfitt, Oxford University Press.

Govan, D. E., Butter, E. D. \& Engelsjerd, G. L. (1968). Urology Digest, 7, i6.

Govan, J. R. W. \& Gillies, R. R. (1969). f. of Med. Microbiol. 2, 17.

Guttmann, L. \& Frankel, H. (1966). Int. F. Paraplegia, 4, 63.

Guze, L. B. \& Beeson, P. B. (I956). New Engl. F. Med. 255, 474.

Miller, A. (1965). Brit. F. Urol. 37, 34.

Milner, P. F. (I963). F. Clin. Path. 16, 39.

Roberts, J. B. M., Linton, K. B., Pollard, B. R., Mitchell, J. P. \& Gillespie, W. A. (1965). Brit. F. Urol. 37, 63.

Stamey, T. A., Govan, D. E. \& Palmer, J. M. (1965). Medicine, 44, I.

TRIBE, C. R. \& Silver, J. R. (1969). Renal Failure in Paraplegia, p. 22. London: Pitman Medical Publishing Co., Ltd.

Wilmot, C. B. \& O’FiYnN, J. D. (1967). Urology Digest, 6, i 7. 